\title{
Staged savagery: Archibald Meston and his Indigenous exhibits ${ }^{1}$
}

\author{
Judith McKay and Paul Memmott
}

Archibald Meston is remembered as the major architect of Queensland's 1897 legislation that was to regulate its Indigenous people for almost a century, and also as its Southern Protector of Aborigines from 1898 to 1904. Meston's contribution as a policymaker and Protector has received much scholarly attention, ${ }^{2}$ however, his activities as a showman - that is, in exhibiting live Indigenous people and himself joining in the performances - are not so well known and have been documented only sporadically. ${ }^{3}$ Even his best known offering, the Wild Australia Show, which was the subject of an exhibition held by the University of Queensland's Anthropology Museum in 2015, ${ }^{4}$ has not been fully explored. This article takes a closer look at Meston's exhibiting activities, which can now be traced more easily with the help of online searching of newspapers. It shows that these activities were central to his policies for solving Queensland's 'Aboriginals problem' and to his work as a Protector, and eventually gained him a national reputation (or notoriety) as a showman. Further, Meston's forays into the sphere of popular entertainment highlight a paradox in the treatment of Indigenous people in Queensland in the late nineteenth and early twentieth centuries, whereby these people were publicly

\footnotetext{
1 The content of this article is partly based on a chapter of Judith McKay's PhD thesis research (see McKay 1996), with additional material on the Wild Australia Show and Meston's ideology from Paul Memmott's parallel research which began in 1980 with work on the Wakaya Land Claim in the Northern Territory and recently culminated in the University of Queensland's exhibition in 2015. (Memmott and others have also received a grant for ongoing research on the Wild Australia Show - ARC LP 160100415.) The authors wish to thank Raymond Evans who kindly read the manuscript and gave useful advice.

2 For example, Thorpe 1984; Evans 1991; Evans, Saunders and Cronin 1993; Ganter and Kidd 1993.

3 Blake 1987: 56-58; McKay 1998: 238-45; Waterson 2000; Walker 2002.

$4 \quad$ Aird et al. 2015.
} 
paraded as 'noble savages' while behind the scenes they were being dispossessed, institutionalised, or at worst, exterminated. Meston's activities also highlight the narrow line of demarcation that existed at the time between ethnology and entertainment, enabling him to claim scientific credibility for his observations of Aboriginal life that were mostly more sensationalist than accurate.

\section{Enter Meston}

Meston was one of Queensland's most colourful personalities of his day, described variously as a journalist, historian, politician, protector, ethnologist, orator, crocodile hunter, athlete and explorer. Born in Scotland in 1851, he emigrated with his parents as a child and spent his early life in the Clarence River district of New South Wales where he learnt the rudiments of farming. Leaving the district in 1869, he worked in a solicitor's office in Sydney and then settled in Queensland five years later, by which time he was already indulging his passions for exploration, shooting and recording Aboriginal language. In Queensland, he worked as a journalist and newspaper editor before being elected in 1878 to the colonial parliament as member for Rosewood; he held the seat until 1882. Thereafter he resumed journalism and moved to Cairns, in the north, where he managed a sugar plantation until bankruptcy forced his return south. In 1889 he led a government-sponsored scientific expedition to the Bellenden-Ker Range, south of Cairns, followed by other expeditions in 1891 and 1904; his explorations earned him membership of the Royal Society of Queensland in 1892. Later, in 1895, he produced his Geographic History of Queensland. In 1909, near the end of his life, he became director of the Queensland Government Tourist Bureau in Sydney. ${ }^{5}$ Not only a jack-of-all-trades, Meston was a complex character. He was vain, arrogant and to some, mean and heartless. Proud of his physique, he supplemented his outdoor activities with weight-lifting and boxing, and always carried a walking stick weighted with lead. According to his obituary published in the World's News of 22 March 1924, he was 'probably the strongest man of his age in Australia'. His appearance, with waxed moustache, carefully coiffed hair and theatrical bearing, was as picturesque as the prose that flowed from his pen. As a contemporary observed, 'he has the heart of a frog hidden under the plumage of a peacock' ${ }^{6}$ Indeed, he was a born showman.

5 Stephens 1974.

6 Newspaper cutting, 'The sultan of Fraser's Island. A cruel monster', June 1902, in Southern Protector of Aboriginals Office, batch files, Queensland State Archives (QSA) item ID717006, 1902/8655. 


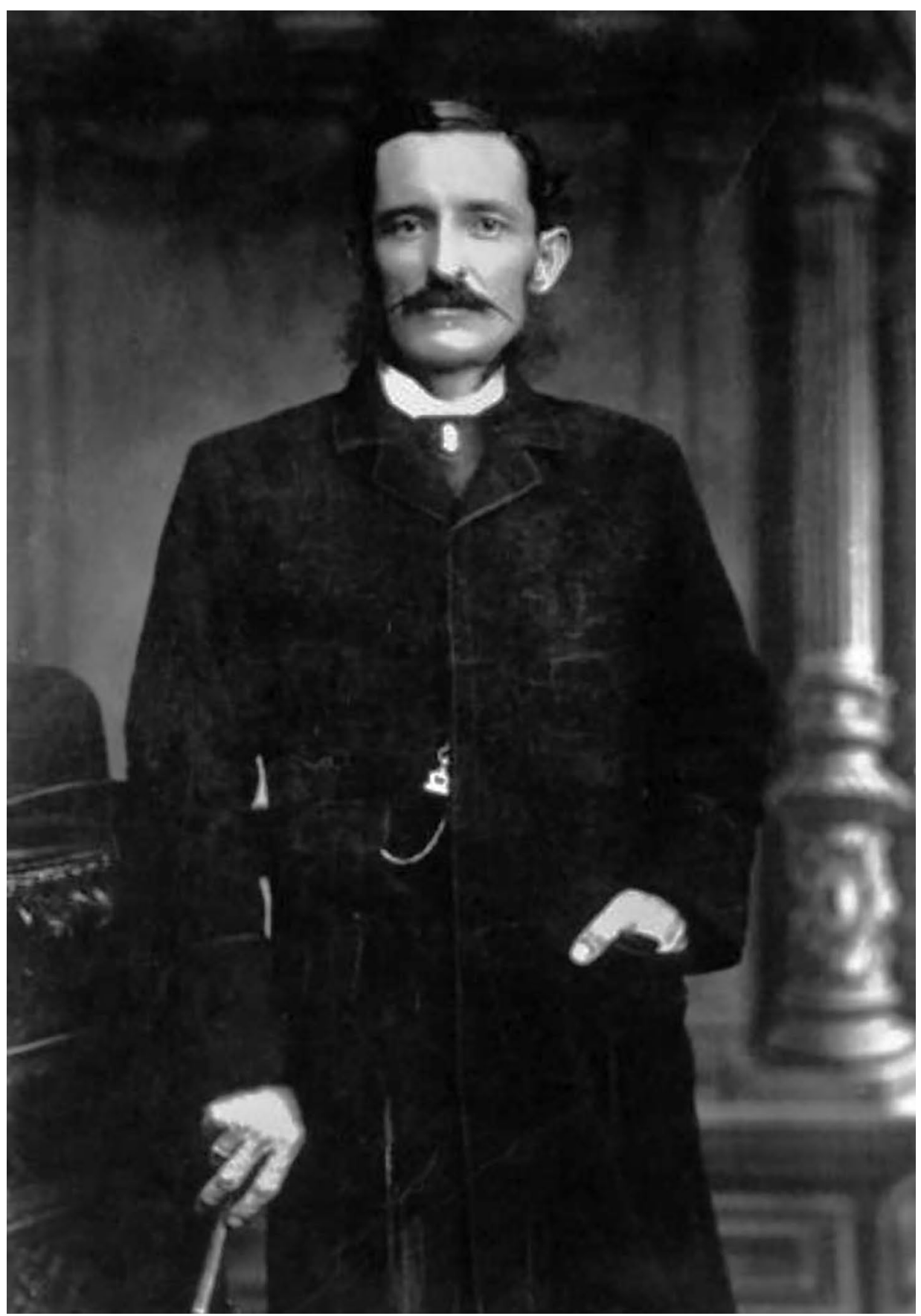

Figure 1: Archibald Meston.

Source: John Oxley Library, State Library of Queensland, image number 17065. 
Growing up in the newly agricultural region of the lower Clarence River Valley, Meston came into contact with Aboriginal people, catalysing his interest in ethnography by his late teens. It was not until his late twenties, when he became editor of the Ipswich Observer and then a parliamentarian, that he began developing his views on Aborigines. ${ }^{7}$ Initially he saw them as treacherous savages who could be ruled only with a gun and spoke openly of killing people with his own gun. ${ }^{8}$ However, he was to modify these views later in the 1880 s when he was living near Cairns, a frontier region that was still under the patrol of the Native Police. Haunted by the spectre of the violence that was decimating Aborigines and observing the demoralised condition of many of the survivors, he appealed to his fellow colonists to extend sympathy to 'a dying race'. Increasingly he saw a future for himself as an 'expert' in Aboriginal ethnology, basing his claim on his supposed mastery of several dialects, his youthful participation in an initiation ceremony on the Clarence, and on his membership of learned societies which gave him some scientific credibility. ${ }^{9}$ By 1891 , when he began his exhibiting activities, he had joined the Brisbane Aborigines Protection Society, in which capacity he visited local missions and settlements. While rejecting the prevailing Social Darwinist ideology that Aborigines were doomed due to the law of natural selection, he formed a complementary view that they were dying due to exposure to alcohol, opium and other urban vices. This was a convenient catchcry for a showman offering glimpses of rare and fast disappearing specimens. But his admiration extended only to those who were fine physical specimens and as yet uncontaminated by the vices of civilisation. He had little time for the 'tobacco-loving blacks' to be seen on the fringes of Australian cities and townships, ${ }^{10}$ posing the threat of 'race mixing'. His live exhibits were all carefully selected for their physical prowess and the visual interest of the 'other'.

\section{Prelude}

Meston made his debut as showman on 29 and 30 September 1891 by presenting two lectures on Aboriginal ethnology at Brisbane's Theatre Royal; these were under the patronage of the Aborigines Protection Society with proceeds to go to the Bribie Island Mission and the Brisbane Hospital. ${ }^{11}$ These so-called 'illustrated lectures' established a pattern that he was to follow in future years. Typically, he would stand before a backdrop of bush scenery, sharing the stage

\footnotetext{
7 Thorpe 1978: 40-43.

8 Ørsted-Jensen 2011: 141; Evans 2010: 20.

9 Thorpe 1978: 22-25. By 1894, Meston was also a member of the Australasian Association for the Advancement of Science and on the committee of the Myora Aboriginal Mission, Dunwich.

10 Queenslander, 10 December 1892: 1149.

11 Telegraph, Brisbane, 30 September 1891: 4; Brisbane Courier, 1 October 1891: 6.
} 
with recreated gunyahs and stuffed native animals, and illustrate what he had to say with lantern slides, artefacts and live people - in this case from the Moreton Bay region. The Aborigines would be elaborately 'made up' with paint, feathers, etc. and bearing weapons to emphasise their savagery, though beneath their finery they would be wearing loincloths or short pants for the sake of modesty. At some point in the proceedings Meston would slip into black tights so he could demonstrate his skill in using native weapons, engaging in mock combats with his performers. As well, the Aboriginal troupe performed corroborees, war dances, nulla-nulla and spear fights; and, ironically, enacted their own demise by staging attacks on white settlers and consequent 'dispersals' by Native Police. Meston used these horrific tableaux to expose the 'wholesale slaughter' of Queensland's (and indeed Australia's) Aboriginal people at the hands of Native Police, an evil that led him to later call for their disbandment. ${ }^{12}$ His message fell on many deaf ears as violent reprisals were accepted practice on Australia's frontiers.

Meston's first lectures were a novelty for an audience of city-dwellers who, by the 1890s, had little contact with tribalised people and may have never before witnessed corroborees and the like. Such representations of savagery appealed to an urban appetite for the exotic and reinforced the notion that Aboriginal people were at the other end of civilisation's scale from white settlers. The lectures were enthusiastically received, so much so that many would-be patrons had to be turned away, and no doubt were a financial success. They provided stimulus for a much more ambitious project, this time commercial rather than charitable.

\section{The 'Wild Australia Show'}

This project, billed as the 'Wild Australia Show' and 'Meston's Wild Australia', was to take a troupe of Queensland Aborigines on a tour of Australia, parts of Europe and eventually, in 1893, to America to perform at the Chicago World's Columbian Exposition which was to include extensive displays of native peoples. ${ }^{13}$ In this venture Meston took on a junior partner, Brabazon Harry Purcell, a Brisbane financial and stock and station agent who had been his stage manager for the recent lectures; he was to continue in this role and share a third of the profits. Following an agreement made on 16 November 1891, the partners borrowed money 'all over the place', including from Patrick Perkins, a local

\footnotetext{
12 An official report of 1896 (published 1897) by William Parry-Okeden, Queensland Police Commissioner, also recognised the excessive brutality of the Native Police; this led to their dismantlement as a paramilitary force in Queensland.

13 The whole Wild Australia saga is recorded in QSA, item ID847483, file 1893/12837; and in Supreme Court reports published in the Brisbane Courier of 22-24 November 1893.
} 
parliamentarian and brewer, and from Meston's brother-in-law, Alfred Shaw of Sydney. ${ }^{14}$ Having secured their funds, the partners travelled around Queensland to recruit 'wild' people and artefacts for their troupe, seeking out examples with distinctive features that would made them particularly curious as show specimens. The press reported that Meston was to concentrate on the Russell River area south of Cairns and the coast north to Cooktown, while Purcell was to go further afield: first to the far west along the Queensland-South Australia border, and later to the north-west in the Normanton region, and thence north to Prince of Wales Island off the tip of Cape York Peninsula. ${ }^{15}$ In July 1892, Purcell's activities in the western border area brought allegations of brutality and forcible abduction from the police magistrate at Boulia, ${ }^{16}$ a charge that Purcell later refuted. Meston's activities also caused concern, as J.T. Embley, a surveyor from the north, reported:

When men like Meston come amongst the blacks they do a great deal of harm by taking their weapons and giving little or nothing in exchange ... I have lately seen a number of natives with whom Meston had come in contact. Their general opinion was 'He no good'. ${ }^{17}$

While recruiting, Meston was annoyed to find that R.A. Cunningham, a Canadian showman and agent for the American Barnum and Bailey Circus, was in the north assembling another troupe for the Chicago exposition. ${ }^{18}$ Meston later stated that he was not impressed by the 'ordinary tame town blacks' his competitor had recruited, adding that he himself would not have bothered with such poor specimens. ${ }^{19}$

14 Letter from Purcell to Colonial Secretary, 21 July 1893, QSA, item ID847483, 1893/12837, in-letter 93/8474. Some of the financiers later withdrew from the venture.

15 Newspaper cuttings, Meston papers, John Oxley Library, Brisbane OM64-17: box 2, items 4 and 5; North Queensland Herald, 8 June 1892: 8; Northern Mining Register, Charters Towers, 8 June 1892: 35.

16 Letter from Meston to Under Colonial Secretary, 18 July 1893, QSA, item ID847483, 1893/12837, in-letter 93/8366.

17 Embley to Commissioner of Police, 3 August 1897, QSA, item ID6826.

18 Poignant 2004: 208-13.

19 Newspaper cutting, Meston papers, John Oxley Library: box 2, item 5. 
Wild Australia! Wild Queensland!

\section{LECTURES ON}

\section{"Wild Australia" and "Wild Queensland" BI

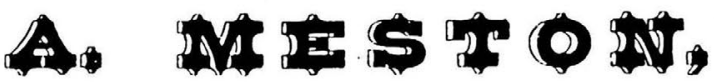 \\ ILLUSTKATED BY \\ THIRTY ABORIGINES:}

Selected chiefly from the Wild Tribes of North Queensland, including several meu and women of that mysterious race who practise what STURT, the explorer, called the "Terrible Rite."

A Collection of orer 3000 Weapons and Ethnological - Specimens from all parts of Australia.

Every phase of aboriginal life as seen by the early settlers of Australia-Hunting, Fighting, Songs, Dances, Corrobborees and "Boorool" (Bora) ceremonies.

The most Exciting, Interesting and Instructive Exhibition of the Nineteenth Century!

WILL APPEAK IN

Brisbane, Sydney, Melbourne,

\section{Adelaide, Tasmania, and New Zealand IN $\cdots$ TOVEMBER,}

ON TIE WAY TO CHICAGO AND A TOUB OF THE WORLD

The Lecturer, Mr. A. MEsTON,

The well-known Queensland Writer and Explorer, is the greatest living Authority on the Habits, Customs, Dialects and Geveral Eitbnology of the Australian aboriginals.

Besides the finest existing Australian Ethnological Collectiun, Mr. Meston will take specimens of all Queensland's Native Produots, and Limelight Pictures of the most beautiful of Queensland's Magnificent Scenery.:

Figure 2: Advertisement for the Wild Australia Show.

Source: Queensland Punch, 1 November 1892. 
Eventually Meston and Purcell rounded up 27 people for their troupe $(21$ men, five women and a child). Among the first to be enlisted were Wakaya people from the central-east of the Northern Territory, taken from around Glenormiston Station on the Georgina River while visiting over the Queensland border. They were particularly prized by Meston and Purcell as members of a tribe noted for practising the sub-incision of males known at the time as 'Sturt's terrible rite', $^{20}$ a practice that fascinated city audiences. Other people were taken from a range of language groups in the McKinlay, Cloncurry, Croydon and Gilbert districts of the north-west, including one Kalkadoon man, a group from the Selwyn-Argylla Ranges who were characterised by Meston and Purcell as fierce cannibals. As well, five people were taken from Prince of Wales Island in the far north, including a so-called king and queen and their child; these were said by Meston to be a link between Australian Aborigines and Papuans of New Guinea. ${ }^{21}$ They were in fact Kaurareg people who identified as an Aboriginal group. Only one of the troupe was taken from southern Queensland; this was Yamurra, said by the press to be 'Meston's favourite', one of the Kabi Kabi people from the Mary River. ${ }^{22}$ Besides rounding up people, Meston and Purcell allegedly collected about 3,000 artefacts, many from the far west and including examples that were said to be previously unknown to whites. It was intended to sell these as they travelled overseas to cover costs.

By late September 1892 the full troupe was brought to Brisbane and subjected to strict medical examination to ensure that all members were healthy. ${ }^{23}$ A rehearsal campsite was established on the north side of the Brisbane River on the site of where the University of Queensland now stands at St Lucia. On 12 November, the troupe travelled upstream to Chelmer to perform for members of the Queensland Press Club who were on a picnic outing aboard the paddle steamer Natone in honour of the visiting English newspaper correspondent Flora Shaw. ${ }^{24}$ This was effectively a dress rehearsal at which the entire troupe was photographed by a government photographer believed to be Will Stark. ${ }^{25}$ The show opened on 5 December 1892 at Brisbane's Her Majesty's Opera House and no effort was spared to create a spectacular entertainment. As the curtain rose 'a typical wild Australian scene' unfolded, with gunyahs and a stuffed kangaroo and emu set against a panoramic backdrop of Mount Bellenden-Ker - a reminder of Meston's northern exploits - painted by the noted scenic artist Carl Frederick Vennemark. Again, Meston delivered his ethnological lectures

\footnotetext{
20 Queenslander, 13 August 1892: 295; Warwick Argus, 8 July 1893: 2.

21 Brisbane Courier, 11 January 1893: 6.

22 Aird et al. 2015: 5. Troupe members have been identified by photographs recently found in various collections in Australia and the United Kingdom; these were taken on the troupe's Australian tour by the wellknown photographers Charles Kerry and Henry King in Sydney and John W. Lindt in Melbourne.

23 Brisbane Courier, 11 January 1893: 6.

24 Queenslander, 19 November 1892: 967. At the time Miss Shaw was Colonial Editor for the London Times.

25 Michael Aird, pers. comm. 20 December 2015. Also see Aird et al. 2015: 8-11.
} 
with the aid of his live exhibits who performed 'every phase of savage life as seen by the early settlers of Australia' ${ }^{26}$ This time, with such a diverse troupe, the performances were more varied, ranging from Kaurareg dances from Prince of Wales Island to Wakaya corroborees from the upper Georgina basin, though at times the whole troupe performed together, joining in pan-tribal synthesised performances of singing and dancing. After a week the show moved to the Breakfast Creek Sportsgrounds and later to the Exhibition Grounds, where the corroborees and boomerang and spear throwing could be seen to better effect and more tableaux and 'pyrotechnic effects' (possibly using electric light) were added. ${ }^{27}$ The night-time performances featured 'campfire displays' and the 'aerial flight of fire-tipped spears and boomerangs'. By popular demand, the show continued in Brisbane until 21 December. Henceforth Meston's presentations were generally both indoors and outdoors, the former comprising lectures and stage performances and the latter involving more athletic display, including by Meston as he pitted his strength against that of his Aboriginal performers.

Though bizarre by today's standards, the show would have been readily acceptable among the 'ethnological' entertainments at its intended destination, the Chicago exposition. At its premiere, the show was likened to the Wild West shows that had toured Australia in the wake of 'Buffalo Bill' Cody's famous re-enactments of the American frontier. ${ }^{28}$ In 1890-91 a former partner of Cody's, 'Dr' Frank Carver, had toured Australia's southern colonies with his Wild America troupe of buck-jump riders, lassoers and American Indian dancers. ${ }^{29}$ Meston and Purcell could have seen similar shows in Brisbane: in early 1891, within a year of Meston presenting his first lectures, Harmston's American Circus and Wirth's Wild West Show came to town..$^{30}$ The lasso throwing and riding stunts that were central to these shows could have inspired the feats performed by Meston's troupe, and they also featured tableaux of frontier violence, though the losers were Indians who attacked stage coaches instead of swagmen's camps. More familiar throughout Queensland, however, were American-based black minstrel shows, which were then at the height of their popularity in Australia and set a derogatory stereotype for black performers. ${ }^{31}$ The well-known Charles B. Hicks's American Colored Minstrels visited Brisbane in 1890-91. Minstrel shows undoubtedly gave Meston's show its burlesque and comic features and could have influenced his own role as an interlocutor figure.

\footnotetext{
26 Queensland Punch, 1 November 1892: 163; Brisbane Courier, 6 December 1892: 5.

27 Brisbane Courier, 21 December 1892: 2.

28 Queensland Punch, 1 January 1893: 16.

29 Brisbane 1991: 118.

30 Brisbane Courier, 7 and 19 February 1891: 5; Boomerang, 14 February, 28 February 1891 and 7 March 1891:10

31 Waterhouse 1990 outlines the impact of minstrelsy in Australia.
} 


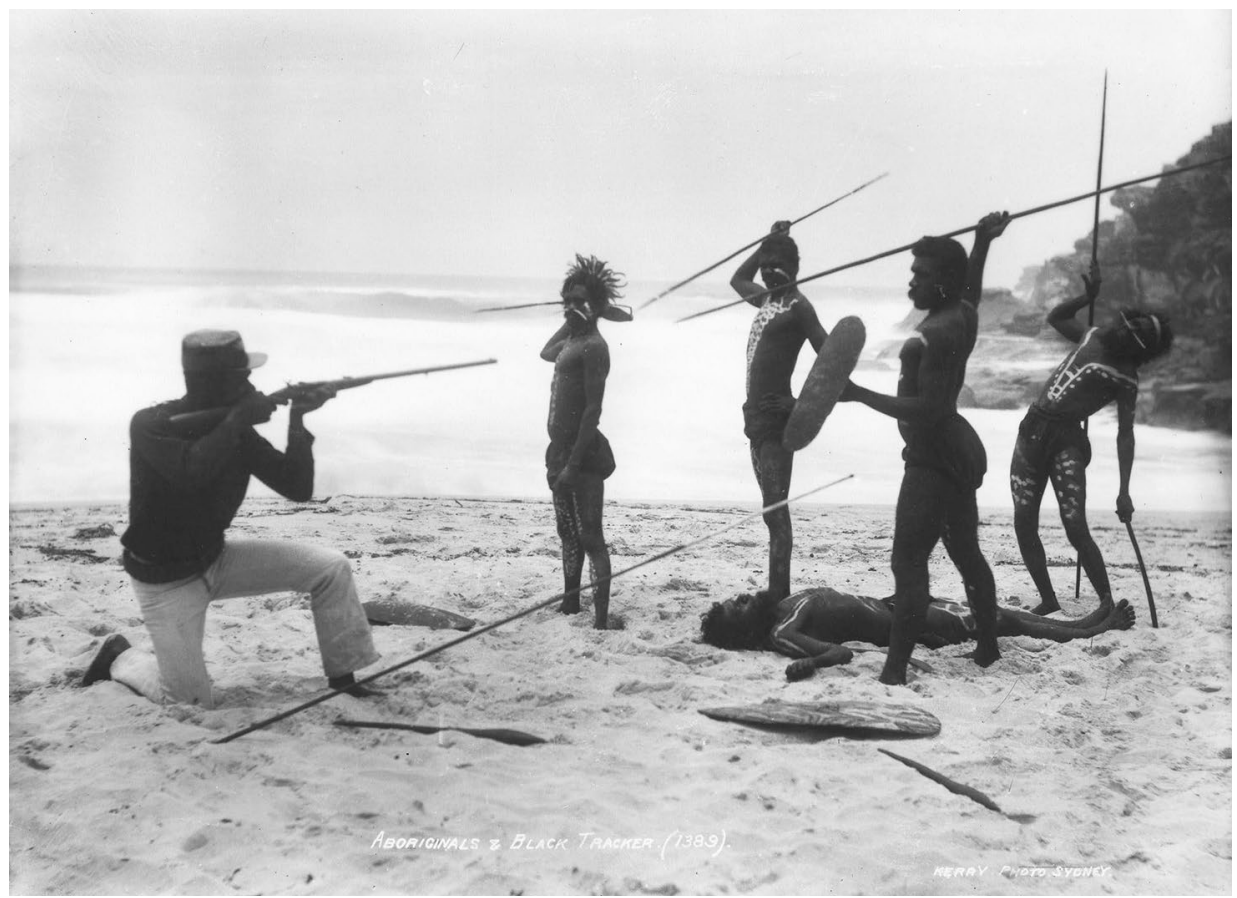

Figure 3: Wild Australia Show tableau of a native trooper 'dispersing' Aboriginal attackers; this was photographed in December 1892 on Sydney's Tamarama Beach near Bondi by Charles Kerry.

Source: Courtesy of Tyrrell Collection, Museum of Applied Arts and Sciences, Sydney.

On 23 December 1892 the Wild Australia troupe left Brisbane by sea for Sydney without any bond or agreement being settled with the Queensland Government, though Meston claimed he had official support. Just before it departed from Brisbane he boasted to his partner: 'The Government won't interfere with me as I know too much about the way they have treated the blacks of this country. ${ }^{\prime 2}$ The first Sydney season was from 26 December at the Bondi Aquarium and later some night-time performances were given at the Sydney School of Arts. Sydney audiences were not so enthusiastic. The Sydney Daily Telegraph panned the show as 'merely an indiscriminate assortment of blackfellows ... having no proper supervision, and run purely as a speculation', though it conceded that the tableau of the massacred swagman was 'worthy of the best efforts of the melodramatic school' ${ }^{33}$ On 24 January 1893 the troupe departed for Melbourne and two days later began performing in the city's famous Exhibition Building. Within a week the performances stopped because the Australian Natives' Association, the sponsor of the troupe's Melbourne visit, broke the contract

32 QSA, item ID847483, 1893/12837, in-letter 93/8474.

33 Sydney Daily Telegraph, 6 January 1893, in box 2, item 5, Meston papers, John Oxley Library; and 9 January 1893: 4. 
on the grounds of having been misled by Meston as to the scale of the show. Realising that the venture would no longer return the profits he expected, and in conflict with Purcell, Meston fled back to Queensland, washing his hands of the venture and leaving Purcell with the outstanding debts and the care and sustenance of the troupe. On 3 February, at short notice, Purcell had to stand in for Meston to provide a guest lecture on Queensland ethnology to the Royal Geographical Society of Australasia's Victorian branch. ${ }^{34}$ Later that month the Victorian police reported that the troupe was left destitute in Fitzroy. ${ }^{35}$

Yet to be defeated, Purcell managed to find enough money to keep the show going. He arranged for more performances to be given at Melbourne's Rotunda Hall in Bourke Street, beginning on 8 March 1893 and continuing into April. To raise public interest in the undertaking, he offered new drawcards, including 'tableaux illustrating the more startling incidents of cannibal life' and lectures to male-only audiences on Sturt's terrible rite, describing the brutal initiation rites he had observed on his Queensland travels. ${ }^{36}$ Purcell and the troupe then returned to Sydney on 22 May to perform at Her Majesty's Theatre. In Sydney, Purcell continued his lectures, speaking on this occasion to the Royal Geographical Society's New South Wales branch, ${ }^{37}$ and on 21 June he directed the troupe's performance in the Domain before the New South Wales Governor. ${ }^{38}$ By July the troupe had run out of engagements and Purcell was no longer able to sustain his charges; it was only then that he abandoned all hopes of reaching Chicago and cabled the Queensland Government for help. ${ }^{39}$ The Queensland Colonial Secretary, Horace Tozer, agreed to repatriate the troupe at government expense, hoping that its fate would be 'an object lesson' for future attempts to abduct Aborigines from Queensland..$^{40}$ Meanwhile, Meston and Purcell squabbled over the project's failure, with Meston accusing his partner of misappropriating funds and stealing the remaining artefacts and scenery, and Purcell accusing Meston of callous contempt. On 14 July 1893, when Purcell and the troupe arrived back in Brisbane, he was arrested on a charge of larceny brought by Meston, but later the charge was dismissed and he countersued Meston for libel and malicious prosecution. Purcell was successful on both counts and his opponent had to pay damages. The court case showed the laxity of the financial arrangements between the two partners and that Meston himself had sold some

\footnotetext{
34 Purcell's Melbourne lecture of 3 February 1893 was published in the Transactions of the Royal Geographical Society of Australasia, Victorian Branch 11, (1894): 17-21.

35 Queenslander, 7 September 1895: 451.

36 Age, Melbourne, 6 March 1893: 5 and 11 March 1893: 8.

37 Purcell's Sydney lecture of June 1893 was published as 'Rites and customs of Australian Aborigines',

Zeitschrift für Ethnologie, Transactions 25, (1893): 286-89.

38 Sydney Morning Herald, 22 June 1893: 4.

39 Letter from Purcell to Under Colonial Secretary, 1 July 1893, QSA, item ID847483, 1893/12837, in-letters 93/7608 and 93/7698.

40 Marginal comment by Tozer, QSA, item ID847483, 1893/12837, in-letter 93/9117.
} 
of the artefacts. Meston lamented that the whole project had cost him '£1200 and two years of valuable time' ${ }^{41}$ The troupe members also had regrets having been left without the wages they had been promised..$^{42}$

\section{Entr'acte}

Despite the Wild Australia fiasco and the tabling of relevant correspondence in the Queensland Parliament, Meston emerged unscathed and his status as an Aboriginal 'expert' enhanced. However, he was anxious to put the fiasco behind him; when reminded of it a few years later, he retorted that 'public interest has long since vanished'. ${ }^{43}$ His former partner, Purcell, was not so fortunate and died in Toowoomba of nervous disorder in 1904, aged only 47 years. ${ }^{44}$ From the time he started exhibiting, Meston called on the Queensland Government to address the plight of the colony's Aboriginal people. He had lost patience by September 1893 when he wrote to Colonial Secretary Tozer: 'This question of the aboriginals is not to be indefinitely postponed. If you decide to do nothing, it will come before the colony in a shape that will not be pleasant for Queenslanders to contemplate. ${ }^{45}$ In 1895 Meston presented Tozer with a lengthy account of his proposals 'to improve and preserve' these vulnerable people, in particular to establish a series of reserves to which they would be removed to protect them from civilisation's vices. Meston's lobbying led to his appointment in March 1896 as a Special Commissioner to report on the condition of Aboriginal people throughout the colony. While undertaking this work he kept exhibiting, for his ambitions as a showman were not quashed by the Wild Australia fiasco. He gave a series of 'illustrated lectures' on 'The tragedies and comedies of early days in Queensland' at various country centres - Ipswich in August 1894, ${ }^{46}$ Maryborough in April-May 1895, Bundaberg in May 1895, ${ }^{47}$ the Northern Rivers district of New South Wales in October $1895,{ }^{48}$ and Cairns in August $1896^{49}$ - using local Aborigines as his live exhibits. Being such a novelty the lectures were well received, though a Maryborough newspaper was not impressed, complaining that Meston presented 'not a connected story, but a miscellaneous collection of narratives of notorious murders, shipwrecks, encounters with blacks $\ldots$ and other entertaining flotsam and jetsam' ${ }^{50}$

41 Queenslander, 14 September 1895: 503.

42 Brisbane Courier, 17 July 1893: 6.

43 Letters to the editor, Queenslander, 29 June 1895: 1226, 6 July 1895: 21, 7 September 1895: 451 and 14 September 1895: 503.

44 Darling Downs Gazette, 28 March 1904: 2.

45 Letter from Meston to Colonial Secretary, 11 September 1893, QSA, item ID847532, 1895/15056.

46 Queensland Times, Ipswich, 4 August 1894: 3.

47 Clarence and Richmond Examiner, Grafton, 25 May 1895: 3.

48 Richmond River Herald, 11 October 1895: 7 and 18 October 1895: 4.

49 Jones 1976: 333.

50 Maryborough Chronicle, 1 May 1895: 2. 


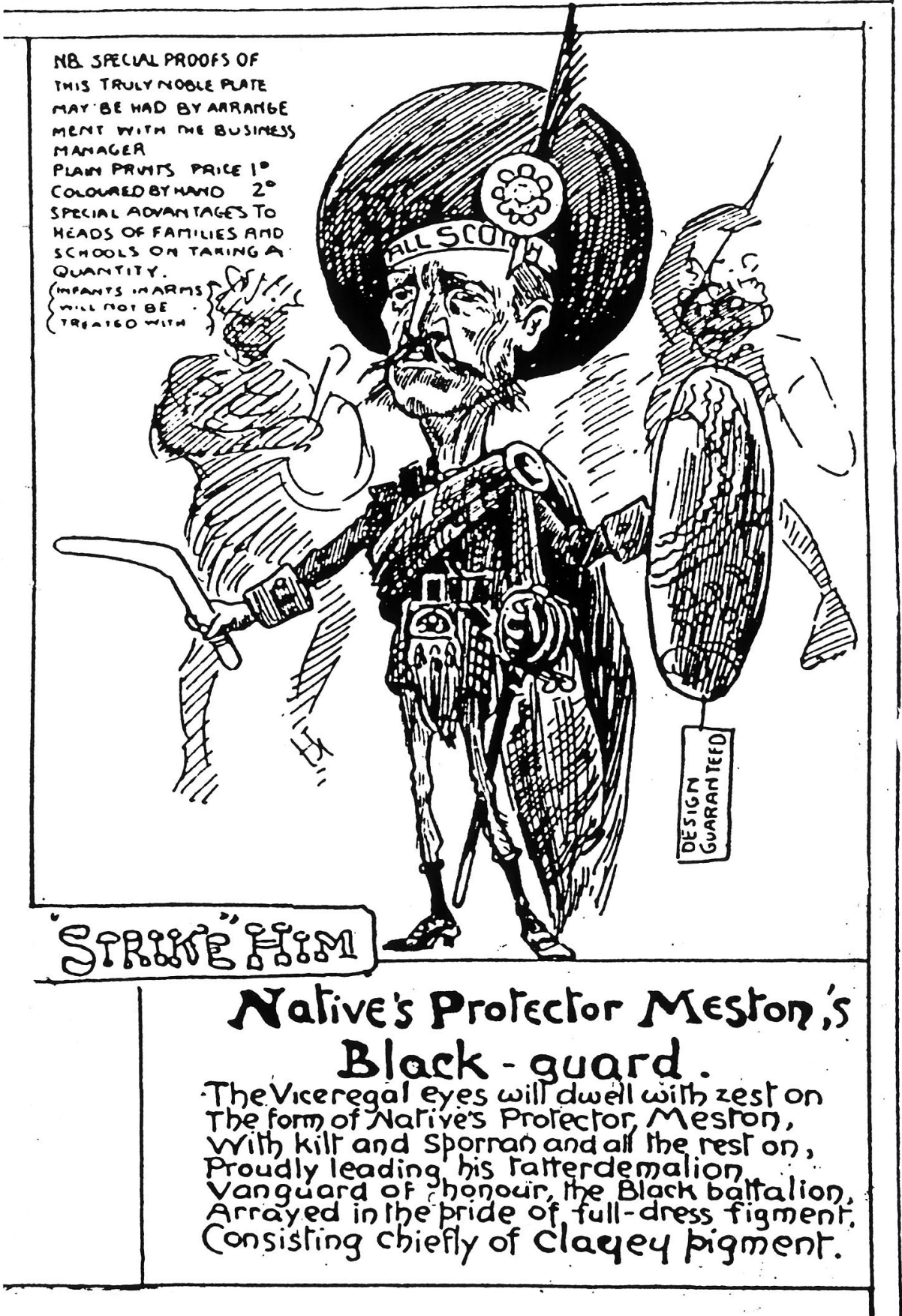

Figure 4: Meston and his warriors welcoming Lord Lamington to Brisbane. Source: The Queenslander, 11 April 1896. 
Meston's finest hour as a showman came in April 1896 when he organised a troupe of 24 Aboriginal warriors to welcome the new Governor, Lord Lamington, to Brisbane. Following the Wild Australia example, he gathered the men from all over Queensland, including from the Russell River, Diamantina and Maranoa districts. On the Governor's arrival they staged a traditional welcome and then formed a 'guard of honour' to accompany the vice-regal procession as it passed through Brisbane's streets. Meston, resplendent as a Scottish chieftain (he was proud of his Scottish heritage), led the band on horseback. As the Queenslander newspaper noted, the procession was 'a triumphal progress' worthy of ancient Rome, with Meston like a victorious general with his band of captives marching behind.51 In August 1897 he organised Aboriginal entertainments for the Queensland International Exhibition. This time he gathered another 30 warriors from various districts, though most came from the Fraser Island Aboriginal Reserve which Colonial Secretary Tozer had established earlier that year on Meston's advice as a precedent for the reserves system. The warriors performed near the exhibition's close, providing a 'most profitable' attraction. Each day they gave demonstrations of boomerang and spear throwing, running and mock combats, and staged corroborees and tableaux, with Meston himself taking an active role. Some of the evening performances had to be moved from the ring into the exhibition buildings due to the cold weather, as the warriors were wearing only paint and feathers. The sight of such 'fine specimens' convinced many visitors of the efficacy of the reserves system. The Brisbane Courier reported:

Only five months ago these men were ... in an utterly demoralised and hopeless condition, under the influence of drink and opium. What they are today the public may see by visiting the Exhibition. Sir Horace [Tozer] deserves hearty congratulations on the success of his humanitarian method. ${ }^{52}$

Visitors were denied access to less impressive specimens; just as the exhibition opened, Meston ensured that all Aboriginal people 'rambling around Brisbane ... in a more or less demoralised condition' would be despatched to reserves. ${ }^{53}$

\section{Protector and showman}

Meston's reports of 1895 and 1896 became the basis of Queensland's Aboriginals Protection and Restriction of the Sale of Opium Act of 1897, which was passed in January 1898 and gave official sanction to the reserves system and also to Meston's appointment as the colony's first Southern Protector of Aborigines.

51 Brisbane Courier, 26 March 1896: 4; Queenslander, 18 April 1896: 724.

52 Brisbane Courier, 31 July 1897: 4 and 3 August 1897: 7.

53 Letter from Meston to Under Home Secretary, 11 May 1897, QSA, item ID17981, 1897/6112. 
His experience in conscripting and drilling Indigenous people as show exhibits can be seen as a rehearsal for his future scenario for these people, overseeing 'abductions' of hundreds of people from their tribal lands across Queensland and removing them to distant reserves under strict regimes of behaviour. In November 1892, just before the Wild Australia Show opened, the Brisbane Courier remarked:

It was not to be supposed that savages gathered as these have been from districts separated by many hundreds of miles, speaking dialects and practising customs which rendered them as strange to each other as they are to the white man, could be brought at once to act in concert. They are now well acquainted with each other and what is required of them..$^{54}$

The success of the drilling process, which had taken over two months, must have given Meston, renowned for his own physical strength, substance for his theory that physical power appealed to Aborigines 'as to other savage races' ${ }^{55}$ Moreover, he used his exhibits to demonstrate the superiority of tribalised people over semi-civilised fringe-dwellers, which was central to his policies. His Wild Australia Show and other entertainments embodied the same notions of control and racial purity, and disregard for attachment to country that underscored his policies. Whereas earlier historiography accepted that the reserves system was motivated by 'humanitarian' concern, Raymond Evans argues that it was a mechanism for keeping Aborigines at a safe distance from whites, unless they could be pressed into cheap labour, and for exerting rigorous control. Evans substantiates that widespread fears of contamination, both hygienic and eugenic, prompted Meston's brutal abductions to these reserves. ${ }^{56}$

It is not surprising that Meston, following his appointment as Southern Protector, should have continued his exhibiting activities, using these to enhance his status and demonstrate the efficacy of the reserves system. In August 1898, soon after his appointment, he proposed taking a troupe from Queensland to the forthcoming Paris Exposition and on to London and Europe, but his proposal was greeted with scorn; ${ }^{57}$ the Australian Town and Country Journal of 8 October 1898 suggested that Londoners could do without 'still another barbarous show from one of the Empire's outposts'. Instead, he had to conserve his energies for the celebrations for the inauguration of the Commonwealth of Australia a few years later. In January 1901, at the request of the New South Wales Premier, he took a party of 25 warriors, originating from various districts in Queensland, to Sydney to participate in a reenactment of Captain Cook's landing at Botany Bay.

\footnotetext{
54 Brisbane Courier, 23 November 1892: 4.

55 Meston 1895: 30. Meston recommended that Aboriginal Protectors be 'men of strong physique'.

56 Evans 1991: 12-18. See Meston 1895: 30 and 1896: 14 where he prescribes the functioning of proposed reserves.

57 Morning Post, Cairns, 11 August 1898: 2.
} 
During the re-enactment, held on 7 January, the men ran down a hill to confront Cook's approaching boat, brandishing their spears and 'looking exceedingly weird and barbaric', ${ }^{58}$ but quickly retreated after one of them was wounded in the leg by musketry fire. The wounded man put on a fine performance, as Melbourne's Argus reported: 'no actor with a life-time of experience behind him could have surpassed the facial expression of the wounded savage, who hobbled off with the whites of his wide open eyes rolling back in a look in which fear, pain, and astonishment were depicted to the very life' ${ }^{59}$ The men's part in the spectacle was applauded and they were invited to give another performance two days later at Botany's Sir Joseph Banks Grounds, thrilling their audience with spear and boomerang throwing and nulla-nulla fights. ${ }^{60}$ Soon afterwards, on 17 January, Meston oversaw a similar performance back in Brisbane; this was for the visit of the Imperial troops who were touring Australia as part of the Federation celebrations. The performance, involving 50 men mostly from the Durundur Aboriginal Reserve, was at night at the Exhibition Grounds. ${ }^{61}$

Meston's greatest contribution to the Federation celebrations was in May 1901 when the Duke and Duchess of Cornwall and York (later King George V and Queen Mary) visited Brisbane while touring Australia after the opening of the first Federal Parliament in Melbourne. For the royal visit, Meston convinced the Queensland Government to erect one of the most spectacular street decorations ever seen in Brisbane, the so-called Aboriginal Arch, erected in George Street near the Executive Building (between Queen and Elizabeth Streets). The most remarkable feature of this towering structure was that it was to support a large group of Aboriginal people drawn from various districts, including the Fraser Island and Durundur Aboriginal reserves, along with a range of artefacts. The idea of using Indigenous people to add spectacle to triumphal arches was not original, having been tried in Queensland since $1868,{ }^{62}$ but it was Meston who took up the idea with flourish. This 'Mestonian triumph' was described by the Queenslander in some detail:

The foundation of the arch is covered with tea-tree bark, carefully and neatly affixed, and this in turn decorated profusely with grass-trees, staghorns, and bird's nest ferns. On top of each buttress is erected a typical aboriginal gunyah, occupied by gins and piccaninnies with emu and kangaroo skins, mats, boomerangs, spears and dillybags, etc., displayed before them. Beneath the arch itself there have been hung strings of beautiful shells, glinting in the sunlight, and surmounting the whole is a magnificent specimen of the grass-tree

\footnotetext{
58 Sydney Morning Herald, 8 January 1901: 5.

59 Argus, Melbourne, 8 January 1901: 5.

60 Correspondence on the Captain Cook re-enactment, QSA, item ID17982, 1901/983; Sydney Morning Herald, 10 January 1901: 5.

61 Brisbane Courier, 16 January 1901: 6; Telegraph, Brisbane, 19 January 1901: 14.

62 McKay 2009: 3-5.
} 
... The arch was manned by no less than sixty aboriginals, ten of whom were $6 \mathrm{ft}$ in height, and the Cooper's Creek man on the apex was $6 \mathrm{ft} 4$ ins. On his right and left were a man from each of the other States ... They were all profusely decorated with emu feathers, and their bodies lined out with red and white ochres, whilst they carried weapons from all parts of Australia. ${ }^{63}$

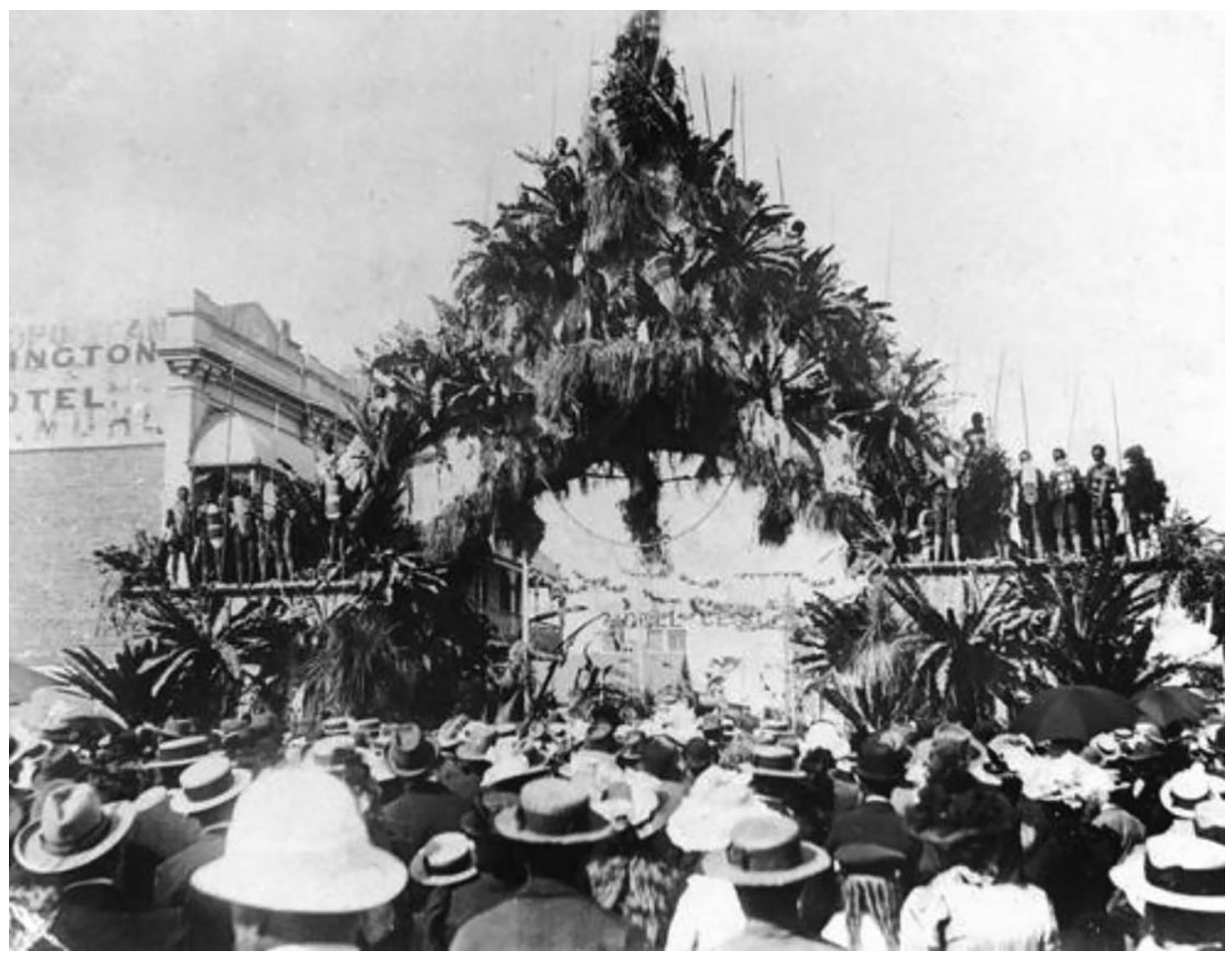

Figure 5: Aboriginal Arch erected in Brisbane for the visit of the Duke and Duchess of Cornwall and York, 1901, a 'Mestonian triumph'.

Source: Courtesy of John Oxley Library, State Library of Queensland, negative number 149581.

The arch was not only wondrous in its variety of Indigenous life, indeed it was 'an excited living arch': on 22 May, as the Duke and Duchess drove beneath, it 'howled and corroboreed ... with all its might'. ${ }^{64}$ The assemblage was applauded by the royals and spectators alike and it was generally agreed that it was the 'the most unique and striking feature' of all the city's decorations. ${ }^{65}$ Later, at night, the men performed a corroboree at Government House where the Duke complimented Meston on their appearance, saying they were the best built and most intelligent-looking coloured men he had seen since leaving London. He also expressed concern for their future welfare; and well

63 Queenslander, 25 May 1901: 977.

64 Newspaper cutting, Meston papers, John Oxley Library: box 2, small cuttings book.

65 Waterson 2000: 47. 
he might, for three of the performers were to die as a result of cold exposure and pneumonia contracted on that occasion. ${ }^{66}$ More performances followed on 23-24 May, this time given at the Woolloongabba Sports Ground. In all, some 80 Aboriginal people were involved in the entertainments for the royal visit, representing a huge organisational effort for Meston. The Queenslander of 1 June 1901 concluded:

Really the Duke and Duchess should not carry away bad impressions of this little colony. In our welcome we gave them Archie Meston's aboriginal arch and his corroborees, something distinctively Australian, while on their way back we managed to cram into an hour or so enough colonial experience to last them for a while.

Following the royal visit Meston kept exhibiting. In February 1903 he staged a spectacular series of performances in Rockhampton to raise funds for the local hospital, involving Aboriginal people from all over Queensland and some from the Northern Territory and South Australia. The performances were so well organised that special excursion trains were run by the Railway Department to bring country patrons, and local brass bands were engaged to add musical accompaniment. ${ }^{67}$ The performances were later repeated in Mount Morgan. By this time, however, Queenslanders were becoming tired of Meston's exhibiting, being so obviously part of his own advancement. In November 1902, when he brought out Fraser Island warriors to entertain the visiting German strongman Eugen Sandow, and at the same time showed off his own skill with a boomerang, the Queensland Figaro newspaper was moved to comment:

Opinions differ as to the treatment which should be shown to travelling showmen like Eugen Sandow, but there cannot be two opinions as to the utter ridiculousness of employing the Protector of Aborigines for the sake of entertaining such visitors with exhibitions of savagery. This sort of thing has passed the farcical stage. Either let Mr Meston start as a state entertainer to globetrotters or compel him to run a nigger company without state aid. ${ }^{68}$

While Meston was exhibiting he was neglecting his other duties and already it was apparent that the reserves system was not arresting the decline of Queensland's Aboriginal population. The reserves functioned more as correctional and custodial institutions, where the regimented and demoralised inmates lacked basic sanitation, medical care and adequate diet. The reserves, as Raymond Evans writes, 'removed the drama of destruction to a remote stage, where it might be played out, unadvertised, in virtually closed houses' ${ }^{69}$ The Fraser

66 Waterson 2000: 48; Evans 2001: 78.

67 Morning Bulletin, Rockhampton, 5-11 February 1903.

68 Queensland Figaro, 6 November 1902: 3.

69 Evans 1991: 27. 
Island Reserve, which Meston had created as a precedent, was handed over to the Anglican Board of Missions in 1900 and finally closed in 1904; many of its inmates already at rest in two very full cemeteries.

\section{Encore}

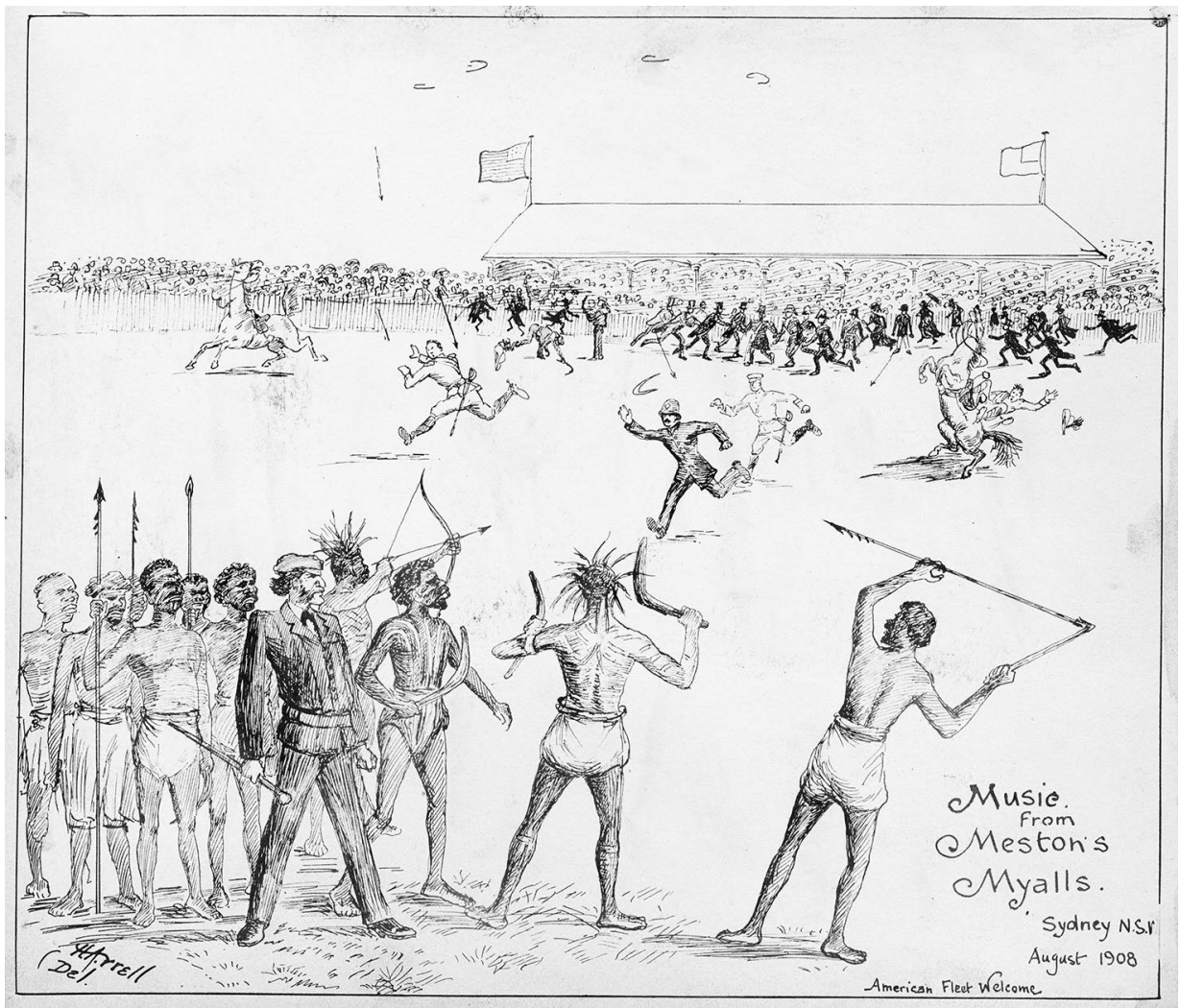

Figure 6: Meston and his troupe performing in Sydney for the visit of the American fleet, 1908, showing spectators fleeing; this is from a drawing by Henry Arrell, a draftsman in the Queensland Survey Office.

Source: Courtesy of Museum of Lands, Mapping and Surveying, Brisbane, accession number M629.

In December 1903 Meston was retrenched as Southern Protector, being replaced by his competitor from the north, Dr Walter Roth, who became Chief Protector for the whole state. Though affronted by his loss of official status, Meston continued to promote himself as an Aboriginal 'expert' and, remarkably, kept exhibiting. In March 1905 he gave a lecture on 'Picturesque Queensland' in Ipswich, using some men from the nearby Deebing Creek settlement as his live 
exhibits. ${ }^{70} \mathrm{He}$ intended to repeat the lecture on a tour to other cities but this failed to eventuate. A few years later, in August 1908, he took a troupe from Queensland, six men drawn from various districts, to Sydney to participate in celebrations for the visit of the American fleet to Australia. In Sydney, they performed at the Royal Agricultural Society Grounds where their boomerang and spear throwing was so impressive that spectators began fleeing, thinking that they would be hit. They also gave a special performance for the GovernorGeneral, the Earl of Dudley, in the grounds of Government House. ${ }^{71}$ Their performances were applauded; the Sydney Morning Herald of 25 August 1908 reported that these were 'the most Australian feature of the whole week's entertainment' for the visiting fleet. A year later, in August 1909, Meston and a larger troupe of 35 men and 5 women gave more displays for the GovernorGeneral on his visit to Brisbane. ${ }^{72}$ Following Meston's appointment in 1909 as director of the Queensland Government Tourist Bureau in Sydney, his exhibiting was curtailed; though he had not run out of steam by 1915 when he wrote to the federal Minister for Defence offering to take a troupe of 100 Queensland warriors to the Western Front, this time to fight rather than entertain. ${ }^{73}$ His final exhibit, again featuring a Queensland troupe, was for a patriotic carnival in Sydney in July 1915. ${ }^{74}$ Archibald Meston died in Brisbane in 1924.

\section{Finale}

Although Meston's Wild Australia Show and his later displays purported to emphasise certain positive traits of Aboriginal people, they effectively portrayed them as the very different 'other' and thereby legitimised Meston's ideas and role in the formulation of the legislation that was to follow. Queensland's Aboriginals Protection Act of 1897, co-drafted by Meston, became a model for the institutionalisation of Indigenous people at a national level, being followed by similar legislation in Western Australia (1905), the Northern Territory (1910) and South Australia (1911). ${ }^{75}$ In hindsight, it is sobering to think that such influential legislation had parts of its origins in ventures to exhibit Indigenous people for profit and amusement. Also that Meston, a man of dubious character and more a showman than a serious scholar of Indigenous culture, should have had been given so much credibility in his day, though it is apparent from the popular media that by no means did all his contemporaries admire him. His contribution to anthropological research in Queensland is now not only

\footnotetext{
Queensland Times, Ipswich, 11 March 1905: 4 and 18 March 1905: 12. Telegraph, Brisbane, 19 August 1908: 7; Singleton Argus, 29 August 1908: 7. Brisbane Courier, 25 August 1909: 4. 
seen as minimal, but confusing, contested, and challenging to deal with in Native Title claim evidence. By contrast, Roth, his peer and rival as a Protector, has left an ethnographic record that, notwithstanding its theoretical limitations for the time, is far more rigorous and valued by anthropology today. There still remain many questions to answer about Meston's various exhibits, not least being the performers' perceptions of their city audiences, to whose fascination with primitiveness and savagery they were pandering.

\section{References}

\section{Primary sources}

Archibald Meston papers OM64-17, John Oxley Library, State Library of Queensland.

Colonial Secretary's Office, correspondence on the Wild Australia Show, Queensland State Archives (QSA) item ID847483, 1893/12837.

Home Secretary's Office, Correspondence on Aborigines, 1896-1903, QSA item ID6826, item ID17981, item ID17982.

Southern Protector of Aboriginals Office, batch files, QSA item ID717006, $1902 / 8655$.

Trove online searching of Australian newspapers.

\section{Secondary sources}

Aird, Michael, Mandana Mapar and Paul Memmott 2015, Wild Australia: Meston's Wild Australia Show 1892-1893, University of Queensland Anthropology Museum, St Lucia.

Blake, Thom 1987, 'Excluded, exploited, exhibited: Aborigines in Brisbane 1897-1910', in Brisbane: Aboriginal, Alien, Ethnic, Rod Fisher (ed.), Brisbane History Group Papers, no. 5, Brisbane History Group, Brisbane: 48-58.

Brisbane, Katharine (ed.) 1991, Entertaining Australia: An Illustrated History, Currency Press, Sydney.

Evans, Raymond 1991, 'A Permanent Precedent': Dispossession, Social Control and the Fraser Island Reserve and Mission, 1897-1904, University of Queensland Aboriginal and Torres Strait Islanders Unit, St Lucia. 
2001, 'Brisbane at Federation: 1899-1902', in Our Federation. Brisbane: Patriotism, Passion and Protest, Barry Shaw (ed.), Brisbane History Group Papers, no. 18, Brisbane History Group, Brisbane: 69-79.

2010, 'The country has another past: Queensland and the history wars', in Passionate Histories: Myth, Memory and Indigenous Australia, Frances Peters-Little, Ann Curthoys and John Docker (eds), ANU E Press, Canberra: 9-38.

Evans, Raymond, Kay Saunders and Kathryn Cronin 1993, Race Relations in Colonial Queensland: A History of Exclusion, Exploitation and Extermination, 3rd edition, University of Queensland Press, St Lucia.

Ganter, Regina and Ros Kidd 1993, 'The powers of Protectors: Conflicts surrounding Queensland's 1897 Aboriginal legislation', Australian Historical Studies 25(101): 536-54.

Jones, Dorothy 1976, Trinity Phoenix: A History of Cairns and District, Cairns and District Centenary Committee, Cairns.

McKay, J.M. 1996, “A Good Show" Colonial Queensland at International Exhibitions', PhD thesis, Department of History, University of Queensland.

McKay, Judith 1998, "A good show": Colonial Queensland at international exhibitions', Memoirs of the Queensland Museum Cultural Heritage Series 1(2): 175-343.

- 2009, 'Celebrating in the streets: A century of triumphal arches', Queensland Review 16(2): 1-14.

Meston, Archibald 1895, Queensland Aboriginals: Proposed System for Their Improvement and Preservation, [Report to H. Tozer, Colonial Secretary], Government Printer, Brisbane.

1896, 'Report on the Aboriginals of Queensland', [Report to H. Tozer, Home Secretary] in Queensland Parliament, Legislative Assembly, Votes and Proceedings, vol. 4, 723-38.

Mitchell, Jessie 2010, "It will enlarge the ideas of the natives": Indigenous Australians and the tour of Prince Alfred, Duke of Edinburgh', Aboriginal History 34: 197-216.

Ørsted-Jensen, Robert 2011, Frontier History Revisited: Colonial Queensland and the 'History War', Lux Mundi Publishing, Brisbane. 
Parry-Okeden, W.E. 1897, 'Report on the Northern Queensland Aborigines and the Native Police, with Appendices', [Presented to both Houses of Parliament by the Police Department, Commissioner's Office] 19 February 1897, in Queensland Parliament, Legislative Assembly, Votes and Proceedings, vol. 2, 23-45.

Petrie, Constance Campbell 1932 [1904], Tom Petrie's Reminiscences of Early Queensland Recorded by His Daughter, Angus \& Robertson Ltd, Sydney.

Poignant, Roslyn 2004, Professional Savages: Captive Lives and Western Spectacle, Yale University Press, New Haven.

Rowley, C.D. 1970, The Destruction of Aboriginal Society, Australian National University Press, Canberra.

1971, Outcasts in White Australia, Aboriginal Policy and Practice vol. II, Australian National University Press, Canberra.

Scott, Joanne and Ross Laurie 2007, 'Colonialism on display: Indigenous people and artefacts at an Australian agricultural show', Aboriginal History 31: 45-62.

Stephens, S.E. 1974, 'Meston, Archibald (1851-1924)', Australian Dictionary of Biography, National Centre of Biography, Australian National University, adb.anu.edu.au/biography/meston-archibald-4191/text6741, published first in hardcopy 1974, accessed online 23 November 2015.

Thorpe, William 1978, Archibald Meston and the Aborigines Ideology and Practice, 1870-1970: An Exploration in Social History', BA (Hons) thesis, Department of History, University of Queensland.

Thorpe, William 1984, 'Archibald Meston and Aboriginal legislation in colonial Queensland', Australian Historical Studies 21(82): 52-67.

Walker, Faith 2002, "The reinvention of the "noble savage": Archibald Meston and "Wild Australia"", Journal of the Royal Historical Society of Queensland 18(3): 130-38.

Waterhouse, Richard 1990, From Minstrel Show to Vaudeville: The Australian Popular Stage 1788-1914, New South Wales University Press, Sydney.

Waterson, Duncan 2000, Above and behind the arches: Aboriginals and the 1901 Federation celebrations', The New Federalist 6: 41-48. 
This text is taken from Aboriginal History, Volume 40, 2016, edited by Liz Conor, published 2016 by ANU Press,

The Australian National University, Canberra, Australia. 